\title{
Stress Response to Long Distance Transportation of Common Carp (Cyprinus carpio L.)
}

\author{
R. DOBŠÍKOVÁ ${ }^{1}$, Z. SVOBODOVÁ ${ }^{1,2}$, J. BLAHOVÁ $^{1}$, H. MODRÁ ${ }^{1}$, J. VELÍŠEK $^{2}$ \\ ${ }^{1}$ University of Veterinary and Pharmaceutical Sciences Brno, Czech Republic \\ ${ }^{2}$ University of South Bohemia České Budějovice, Czech Republic \\ Received October 27, 2006 \\ Accepted April 13, 2006
}

\begin{abstract}
Dobšíková R., Z. Svobodová, J. Blahová, H. Modrá, J. Velíšek: Stress Response to Long Distance Transportation of Common Carp (Cyprinus carpio L.). Acta Vet Brno 2006, 75: 437-448.

The stress responses and changes in biochemical and haematological indices were investigated in three-year-old common carp (Cyprinus carpio L.) during a long-distance transportation in special truck tanks. Twelve-hour transportation caused a significant increase in ammonia $(p<$ $0.01)$, mean corpuscular volume $\operatorname{MCV}(p<0.01)$, metamyelocytes $(p<0.05)$ and band neutrophils $(p<0.01)$, and a significant decrease in $\mathrm{Cl}^{-}(p<0.05)$, lactate $(p<0.05)$, ALT $(p<0.05)$ and ALP $(p<0.01)$ levels. The values of LDH $(p<0.01)$, AST $(p<0.05)$, CK $(p<0.01)$ and haematocrit PCV $(p<0.05)$ were also significantly influenced by the transportation, but no time-dependent relation was found. On the contrary, the levels of cortisol, glucose and total protein in the biochemical profile, and the values of erythrocyte count (RBC), haemoglobin $(\mathrm{Hb})$, mean corpuscular haemoglobin (MCH), mean corpuscular haemoglobin concentration (MCHC), leukocyte counts (WBC) and leukogram (except for metamyelocytes and band neutrophils) in the haematological profile were not significantly influenced by the transportation. Results showed that pre-transport fish manipulation (hauling, netting, handling, loading) was found to be an important stressor for fish. Long-distance transportation itself was relatively considerate for the common carp tested.
\end{abstract}

Fish, transport, haematological parameters, biochemical parameters

In food animal industries, handling and transport are often stressful events. In fish aquaculture, the processes of grading, capturing (most commonly by netting), transferring out of water and transporting fish are inherently stressful, and lead to a "fight or flight" stress response (Barton et al. 1980). This response causes the primary release of adrenalin and cortisol, which is followed by secondary changes in blood and tissues, such as hyperglycemia, hyperlactemia, hypercholesterolemia, changes in blood plasma enzyme activity and ion concentrations, reduced glycogen content in muscle and liver, an increase in metabolic rate, and also shifts in haematological profile and immunological capacity (Mazeaud et al. 1977; Staurnes et al. 1994; Stave and Robertson 1985).

Transporting live fish is a multiple-phase operation that should be designed to minimize stress and the costs involved. Transport of fish by tank trucks requires a special care to ensure that water quality parameters (temperature and oxygen content, in particular) and fish density requirements are maintained. Transport stress may be often caused by low oxygen levels, temperature differences between storage pond and tank water, or poor transport water quality due to inadequate water exchange that cause accumulation of carbon dioxide and ammonia (Eriks on et al. 1997). Excretory products, mucus and regurgitated food degrade water quality. Respiration causes a decrease in dissolved oxygen levels and an increase in carbon dioxide levels in the transport medium. The excretion of nitrogenous wastes increases the level of ammonia in the transport medium. The increase in carbon dioxide concentration causes water $\mathrm{pH}$ to decrease.

Address for correspondence:

MVDr. Radka Dobšíková, Ph.D.

University of Veterinary and Pharmaceutical Sciences

Palackého 1-3, 61242 Brno

Czech Republic
Phone: + 420541562784

Fax: + 420541562790

E-mail: dobsikovar@vfu.cz

http://www.vfu.cz/acta-vet/actavet.htm 
Stress and muscle activity during transportation procedures usually shorten the time to the onset of rigor mortis, which is essentially triggered by the depletion of glycogen and ATP in muscle cells. Handling and processing of fish during rigor mortis can result in a loss of quality and lower fillet yield. The pre-rigor period must be long enough to ensure that bleeding, gutting, washing, chilling and packing take place before the onset of rigor mortis. Ante-mortem handling stress has also adverse effects on product quality such as reducing fish freshness and softening muscle texture (Izquierdo-Pulido et al. 1992; Nakay a ma et al. 1994).

The objective of this study was to assess the transport stress response, i.e. the effect of pretransport manipulation procedures (hauling, netting, handling and loading) and transportation itself on changes in selected biochemical and haematological indices of threeyear-old common carp (Cyprinus carpio L.) during a long-distance transportation. Transport water quality parameters were also monitored.

\section{Materials and Methods}

The experiment was carried out during a regular transport (April 29, 2005) of fish from storage ponds at a commercial fish farm in Hluboká nad Vltavou via Brno (Czech Republic) to a fish-pond in Bohelov (Slovakia). Carp were held in a freshwater flow-through storage pond for three days prior to transport, and then transferred to $2.4 \mathrm{~m}^{3}$ transport tanks (loading density of $334 \mathrm{~kg}$ body weight $\cdot \mathrm{m}^{-3}$ ). Fish were transported in long-distance transporting tanks (AGK Kronawitter $\mathrm{GmbH}, \mathrm{Germany}$ ) that were insulated and continuously aerated with gas oxygen during the transport. The transport took 12 hours in total, 7 hours from Hluboká nad Vltavou to Brno and 5 hours from Brno to Bohelov.

Water quality variables were registered throughout the experiment, the results are given in Table 1 . The values of temperature and oxygen content were measured in situ (WTW pH 235), and $\mathrm{pH}, \mathrm{NH}_{4}^{+}, \mathrm{Cl}^{-}$, acid neutralisation capacity $\left(\mathrm{ANC}_{4.5}\right)$ and chemical oxygen demand $\left(\mathrm{COD}_{\mathrm{Mn}}\right)$ were measured in laboratory.

The fish population tested consisted of 47 fish. Blood samples were withdrawn by cardiocenthesis before transport (i.e. during fish transfer from the storage pond to truck tanks) in Hluboká nad Vltavou (16 individuals), and after 7 and 12 hours of transport, in Brno (15 individuals) and Bohelov (16 individuals), respectively. In situ, haematocrit (PCV) was measured and leukogram blood smear prepared. A small volume of heparinized blood was reserved at $4{ }^{\circ} \mathrm{C}$ for red and white blood cell counts (RBC, WBC) and haemoglobin content $(\mathrm{Hb})$ (Svobodová et al. 1991). The rest of heparinized blood was centrifuged at $3000 \mathrm{rpm}$ for $10 \mathrm{~min}$ and plasma samples were stored at $4{ }^{\circ} \mathrm{C}$ in Eppendorf test-tubes until analyses were performed (i.e. within 8 hours after blood sampling).

Plasma biochemical indices (glucose, lactate, LDH, CK, ALT, AST, ALP, ammonia, chloride, total protein) were measured by a biochemical analyzer Cobas EMira using commercial test kits. Plasma cortisol concentration was measured using HPLC/DAD (Waters).

Experimental data were statistically tested using variance analysis of the Statistica 6.0 software (Kruskal Wallis ANOVA).

\section{Results}

The results of water samples analysis are given in Table 1 and the values (mean \pm SD) of biochemical and haematological indices of the common carp tested are presented in Table 2 and Table 3 , respectively.

Table 1. Variables of the transport water tested (controlled aeration).

\begin{tabular}{|l|c|c|c|}
\hline Parameters & Hluboká & Brno & Bohelov \\
\hline temperature $\left({ }^{\circ} \mathrm{C}\right)$ & 12.6 & 12.1 & 12.0 \\
\hline oxygen $(\%)$ & 21.9 & 55.7 & 116.2 \\
\hline $\mathrm{pH}$ & 7.39 & 6.46 & 6.57 \\
\hline $\mathrm{ANC}_{4.5}\left(\mathrm{mmol} \cdot \mathrm{l}^{-1}\right)$ & 2.0 & 2.0 & 2.2 \\
\hline $\mathrm{COD}_{\mathrm{Mn}}\left(\mathrm{mg} \cdot \mathrm{l}^{-1}\right)$ & 12.8 & 29.7 & 44.8 \\
\hline $\mathrm{NH}_{4}^{+}\left(\mathrm{mg} \cdot \mathrm{l}^{-1}\right)$ & 1.19 & 8.69 & 13.00 \\
\hline $\mathrm{Cl}^{-}\left(\mathrm{mg} \cdot \mathrm{l}^{-1}\right)$ & 27.37 & 35.42 & 40.25 \\
\hline
\end{tabular}


Mean values of body length, body weight and spleen weight $(41.1 \pm 4.13 \mathrm{~cm}, 1213.1$ $\pm 322.07 \mathrm{~g}$ and $3.1 \pm 0.93 \mathrm{~g}$ in Hluboká nad Vltavou, $39.6 \pm 5.41 \mathrm{~cm}, 1203.3 \pm 540.99 \mathrm{~g}$ and $4.1 \pm 1.74 \mathrm{~g}$ in Brno, and $40.0 \pm 3.89 \mathrm{~cm}, 1196.9 \pm 367.18 \mathrm{~g}$ and $3.9 \pm 1.32$ in Bohelov, respectively) did not differ statistically among the groups tested.

In the study, the value of SSI ("spleen/soma index", i.e. relative weight of spleen) was also tested. The values of relative spleen weight were found $0.27 \pm 0.088 \%, 0.34 \pm 0.089 \%$, and $0.33 \pm 0.077 \%$ in Hluboká nad Vltavou, Brno, and Bohelov, respectively. No significant difference in the SSI indice among the groups tested was found.

Results of plasma biochemical profile of experimental groups of common carp exposed to long-distance transportation (Fig. 1) showed a significant increase in ammonia $(p<0.01)$, and a significant decrease in chloride $(p<0.05)$, lactate $(p<0.05)$, ALT $(p<0.05)$ and ALP $(p<$ $0.01)$ values. The values of LDH $(p<0.01)$, AST $(p<0.05)$ and CK $(p<0.01)$ were significantly influenced by the transport, too, but no time-dependent relation was found. The concentrations of cortisol, glucose and total protein were not significantly changed (Table 2).

Table 2. Biochemical indices of common carp during long-distance transportation.

\begin{tabular}{|l|c|c|c|}
\hline Indices & $\begin{array}{c}\text { Hluboká } \\
\text { Mean } \pm \text { SD }\end{array}$ & $\begin{array}{c}\text { Brno } \\
\text { Mean } \pm \text { SD }\end{array}$ & $\begin{array}{c}\text { Bohelov } \\
\text { Mean } \pm \text { SD }\end{array}$ \\
\hline Cortisol $\left(\mathrm{ng} \cdot \mathrm{ml}^{-1}\right)$ & $213.3 \pm 61.88^{\mathrm{a}}$ & $206.6 \pm 42.48^{\mathrm{a}}$ & $201.6 \pm 36.38^{\mathrm{a}}$ \\
\hline Glucose $\left(\mathrm{mmol} \cdot \mathrm{l}^{-1}\right)$ & $8.2 \pm 1.50^{\mathrm{a}}$ & $8.7 \pm 2.20^{\mathrm{a}}$ & $9.4 \pm 2.58^{\mathrm{a}}$ \\
\hline LDH $\left(\mu \mathrm{kat} \cdot \mathrm{l}^{-1}\right)$ & $10.2 \pm 3.09^{\mathrm{a}}$ & $14.7 \pm 0.89^{\mathrm{b}}$ & $9.9 \pm 6.16^{\mathrm{a}}$ \\
\hline AST $\left(\mu \mathrm{kat}^{-1} \mathrm{l}^{-1}\right)$ & $2.2 \pm 1.17^{\mathrm{a}}$ & $3.4 \pm 0.81^{\mathrm{b}}$ & $2.5 \pm 1.23^{\mathrm{a}}$ \\
\hline CK $\left(\mu{\left.\text { kat. } \mathrm{l}^{-1}\right)}^{\text {Total protein }\left(\mathrm{g} \cdot \mathrm{l}^{-1}\right)}\right.$ & $375.1 \pm 137.46^{\mathrm{a}}$ & $761.8 \pm 457.44^{\mathrm{bc}}$ & $588.2 \pm 411.57^{\mathrm{ac}}$ \\
\hline
\end{tabular}

Note: Groups with different alphabetic superscripts differ significantly.

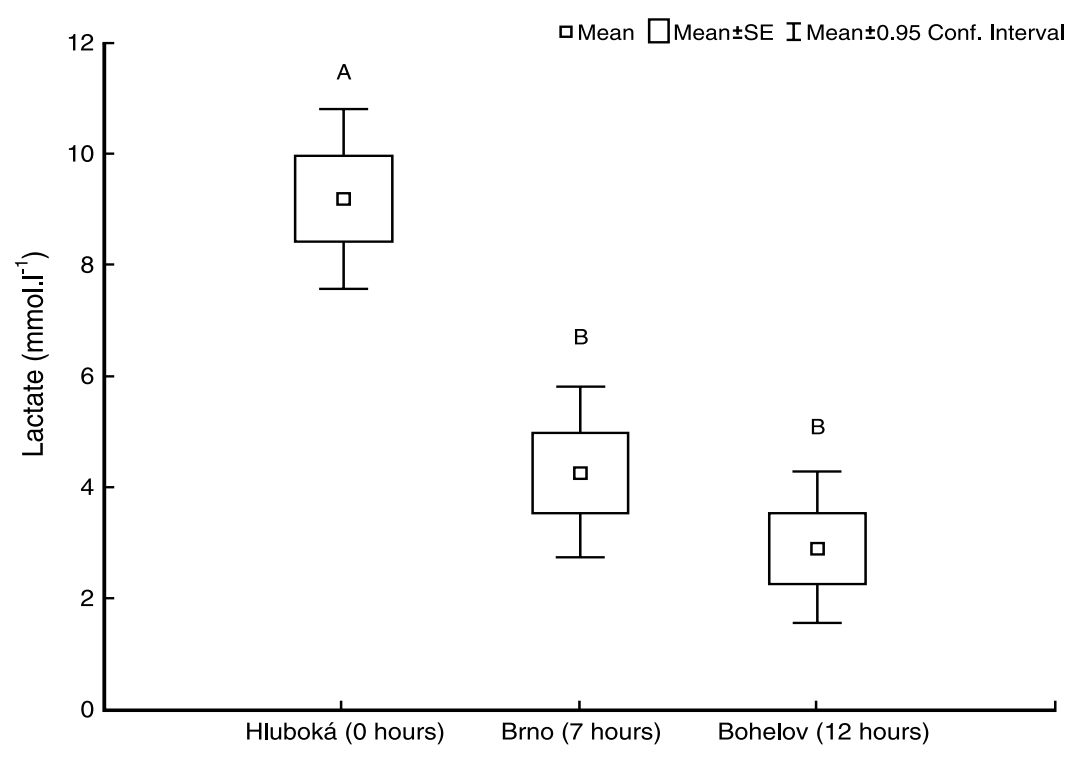

Fig. 1a. Plasma lactate concentration of common carp during long-distance transportation. Note: Columns with different alphabetic superscripts differ significantly. 

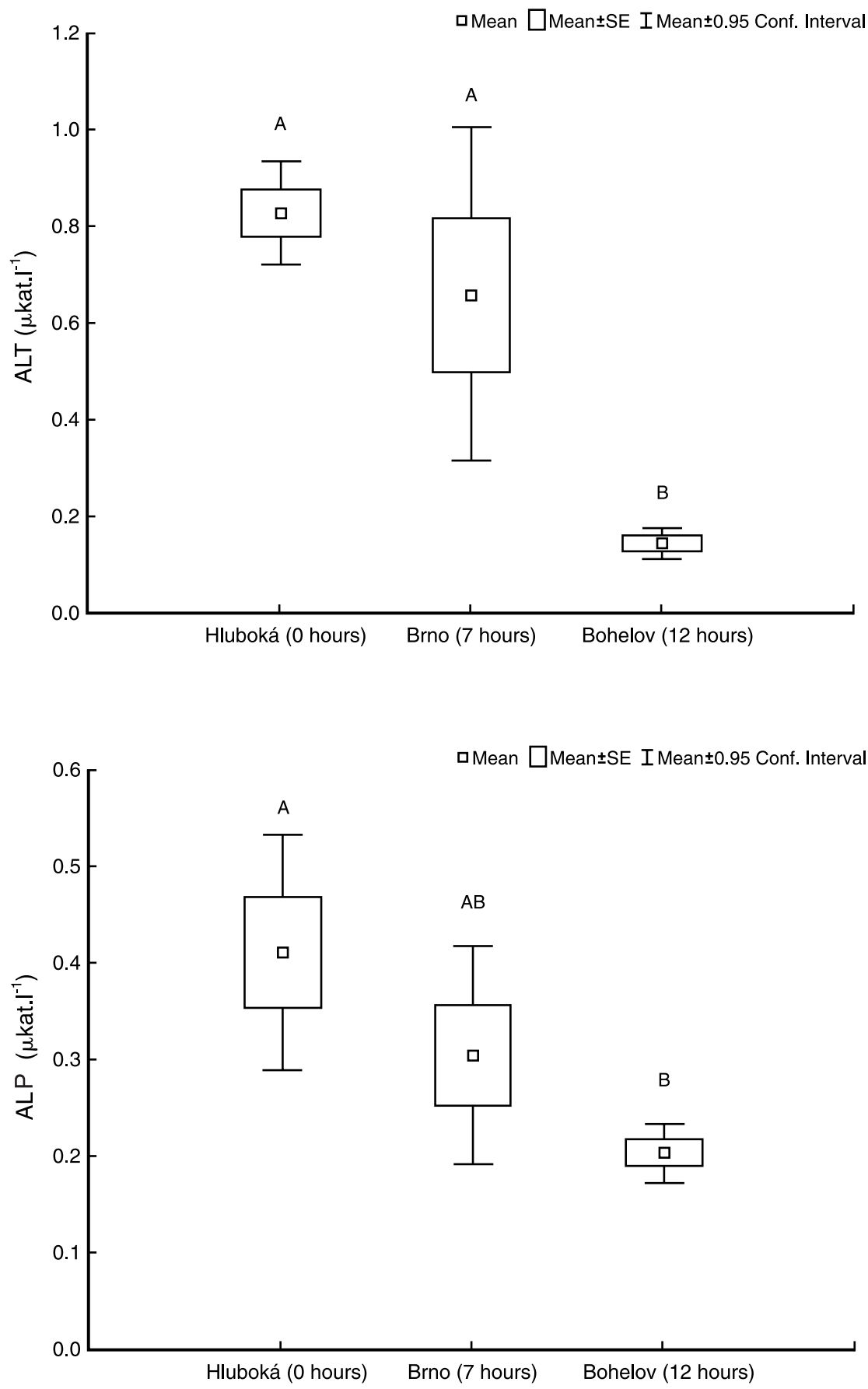

Fig. 1b, c. Plasma ALT and ALP activities of common carp during long-distance transportation. Note: Columns with different alphabetic superscripts differ significantly. 

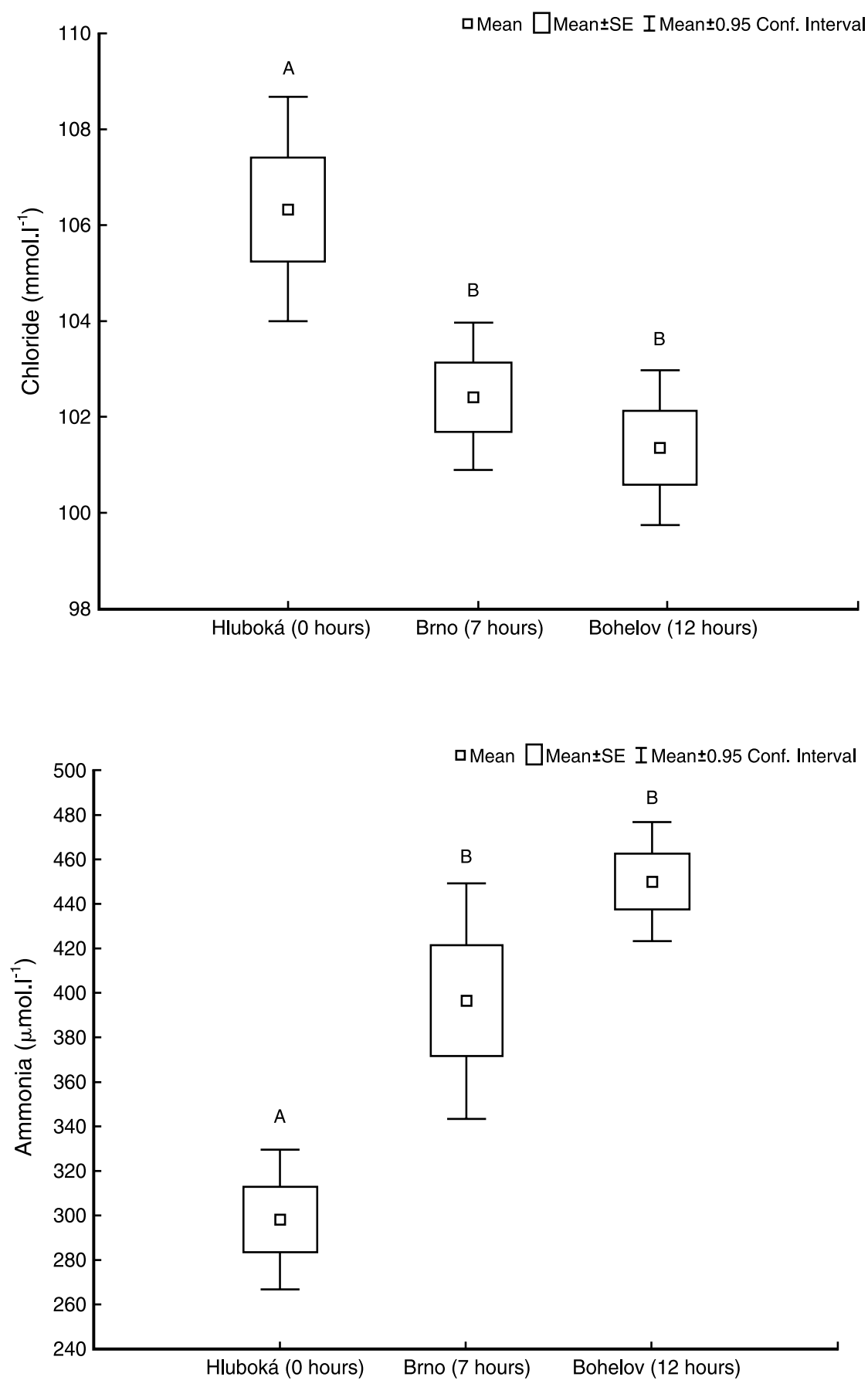

Fig. 1 d, e. Plasma chloride and ammonia concentrations of common carp during long-distance transportation. Note: Columns with different alphabetic superscripts differ significantly. 
As far as the haematological indices are concerned (Fig. 2), the long-distance transport caused a significant increase in MCV $(p<0.01)$, metamyelocytes counts $(p<0.05)$ and band neutrophils counts $(p<0.01)$. The values of PCV $(p<0.05)$ were also significantly changed without the confirmation of time-dependent relation. The other haematological indices tested were comparable within the groups (Table 3).

Table 3 Haematological indices of common carp during long- distance transportation.

\begin{tabular}{|l|c|c|c|}
\hline Indices & $\begin{array}{c}\text { Hluboká } \\
\text { Mean } \pm \text { SD }\end{array}$ & $\begin{array}{c}\text { Brno } \\
\text { Mean } \pm \text { SD }\end{array}$ & $\begin{array}{c}\text { Bohelov } \\
\text { Mean } \pm \text { SD }\end{array}$ \\
\hline RBC $\left(\mathrm{T} \cdot \mathrm{l}^{-1}\right)$ & $1.46 \pm 0.175^{\mathrm{a}}$ & $1.46 \pm 0.193^{\mathrm{a}}$ & $1.38 \pm 0.225^{\mathrm{a}}$ \\
\hline $\mathrm{PCV}\left(\mathrm{l} \cdot \mathrm{l}^{-1}\right)$ & $0.32 \pm 0.027^{\mathrm{a}}$ & $0.36 \pm 0.044^{\mathrm{b}}$ & $0.36 \pm 0.028^{\mathrm{b}}$ \\
\hline $\mathrm{Hb}\left(\mathrm{g} \cdot \mathrm{l}^{-1}\right)$ & $94.74 \pm 28.047^{\mathrm{a}}$ & $92.68 \pm 15.463^{\mathrm{a}}$ & $93.43 \pm 9.875^{\mathrm{a}}$ \\
\hline $\mathrm{MCH}(\mathrm{pg})$ & $65.49 \pm 21.108^{\mathrm{a}}$ & $64.02 \pm 9.772^{\mathrm{a}}$ & $69.11 \pm 12.329^{\mathrm{a}}$ \\
\hline $\mathrm{MCHC}\left(\mathrm{l} \cdot \mathrm{l}^{-1}\right)$ & $0.30 \pm 0.084^{\mathrm{a}}$ & $0.27 \pm 0.048^{\mathrm{a}}$ & $0.26 \pm 0.028^{\mathrm{a}}$ \\
\hline $\mathrm{WBC}\left(\mathrm{G} \cdot \mathrm{l}^{-1}\right)$ & $57.56 \pm 32.932^{\mathrm{a}}$ & $76.33 \pm 45.613^{\mathrm{a}}$ & $79.94 \pm 28.963^{\mathrm{a}}$ \\
\hline Lymphocytes $\left(\mathrm{G} \cdot \mathrm{l}^{-1}\right)$ & $51.02 \pm 33.147^{\mathrm{a}}$ & $65.32 \pm 42.681^{\mathrm{a}}$ & $63.74 \pm 26.855^{\mathrm{a}}$ \\
\hline Monocytes $\left(\mathrm{G} \cdot \mathrm{l}^{-1}\right)$ & $0.91 \pm 0.678^{\mathrm{a}}$ & $0.73 \pm 0.968^{\mathrm{a}}$ & $0.52 \pm 1.494^{\mathrm{a}}$ \\
\hline Myelocytes $\left(\mathrm{G} \cdot \mathrm{l}^{-1}\right)$ & $1.98 \pm 1.944^{\mathrm{a}}$ & $2.17 \pm 1.500^{\mathrm{a}}$ & $2.74 \pm 1.995^{\mathrm{a}}$ \\
\hline Segmented neutrophils $\left(\mathrm{G} \cdot \mathrm{l}^{-1}\right)$ & $0.82 \pm 1.047^{\mathrm{a}}$ & $0.92 \pm 1.003^{\mathrm{a}}$ & $0.62 \pm 0.988^{\mathrm{a}}$ \\
\hline Basophils $\left(\mathrm{G} \cdot \mathrm{l}^{-1}\right)$ & $0.03 \pm 0.089^{\mathrm{a}}$ & $0.00 \pm 0.000^{\mathrm{a}}$ & $0.13 \pm 0.392^{\mathrm{a}}$ \\
\hline
\end{tabular}

Note: Groups with different alphabetic superscripts differ significantly.

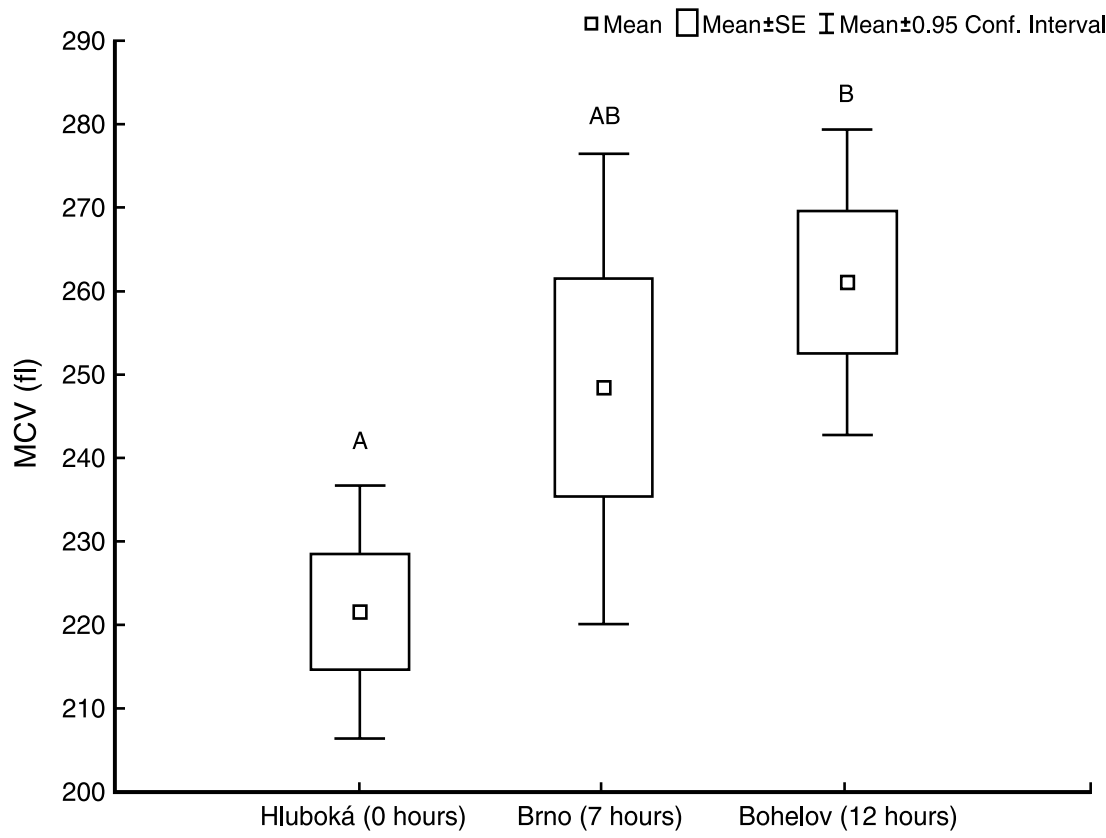

Fig. 2a. MCV value of common carp during long-distance transportation. Note: Columns with different alphabetic superscripts differ significantly. 

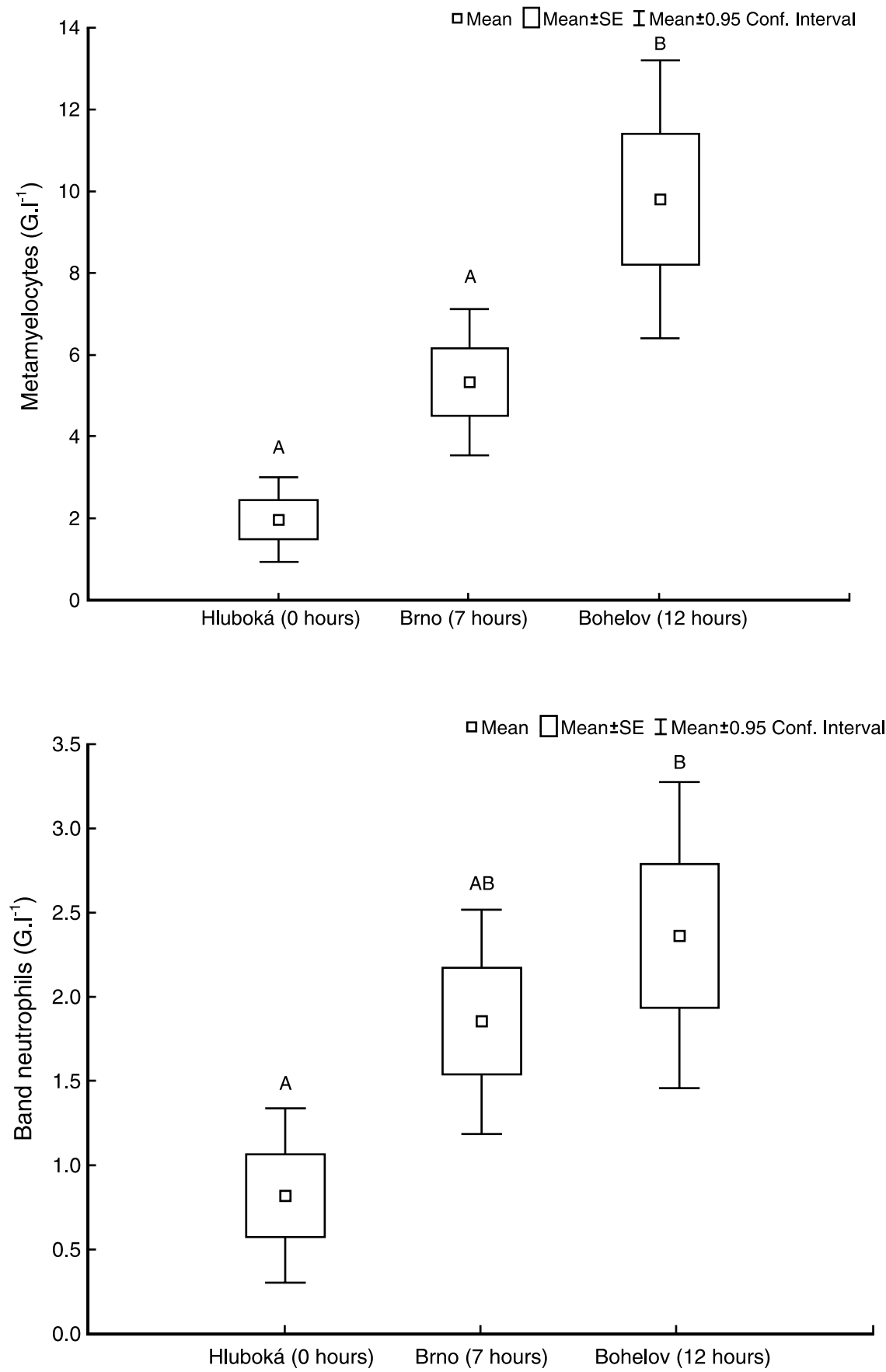

Fig. 2b, c. Metamyelocytes counts, and band neutrophil counts of common carp during long-distance transportation.

Note: Columns with different alphabetic superscripts differ significantly. 


\section{Discussion}

Recent studies show that one of the most important factors that affect the fish welfare during short- or a long-distance transport, is an adequate adjustment and stress reduction in fish by minimization of manipulation procedures, pre-transport defecation to prevent the accumulation of metabolites in transport medium, as well as the avoidance of temperature and light changes, using anaesthetics, etc. (S vobodová et al. 1999) .

None of the water-quality parameters measured (Table 1) suggested that adverse water quality prevailed at any time during long-distance transportation.

Being vulnerable to short-term temperature fluctuations, necessary care must be taken when transferring fish to new ponds or new culture or transport media until acclimatized (Roberts and Shepherd 1997). In our experiment, storage pond and truck tank water temperatures were found similar (i.e. approximately $12.5^{\circ} \mathrm{C}$ ). As for common carp, a critical value of oxygen saturation in water is $12.0 \%$ and $15.3 \%$ at 10 and $15{ }^{\circ} \mathrm{C}$, respectively (S vobodová et al. 2003). In the study, transport water oxygen content increased markedly during the fish transportation due to continual aeration, and was sufficient for the fish.

The value of $\mathrm{pH}$ slightly decreased during the transport, nevertheless, it held within the optimum range 6.4 - 8.4 (Roberts and Shepherd 1997). The elevated COD $_{M n}$ value and the levels of ammonia and chloride in transport medium may be ascribed to higher fish metabolic rate in a relatively high-density tank volume.

Pre-transport manipulation, i.e. capturing and reloading fish into transport tanks, appeared to be a severe stressor to fish. In accordance with our findings, some previous studies proved that capture-loading manipulation (hauling, netting, catching, reloading) is the major cause of the transport stress response (Schreck et al. 1989; Weireich and Tomasso 1991). Robertson et al. (1987), Pottinger (1998) and Ruane et al. (2001) reported that manipulation with fish in general (capturing, confinement, increased stocking density, transportation, etc.) lead to the elevation of plasma cortisol, glucose and lactate concentrations. Ruane et al. (2001) reported that during net-confinement, plasma cortisol levels increased rapidly after $30 \mathrm{~min}$ to reach the concentrations of $240-320 \mathrm{ng} \cdot \mathrm{ml}^{-1}$. Robertson et al. (1987) reported that cortisol concentrations increased with the increase of transport time. On the basis of our study results, we assume that pre-transport manipulation lead to the increase of plasma cortisol. The increased concentration of cortisol lasted throughout the transportation.

Plasma glucose levels are elevated in stressed fish as a consequence of the increase of blood catecholamine levels. Nevertheless, the index is a more equivocal index of stress than cortisol, as plasma glucose is a function of many factors (diet, age, season, etc.). In our study, glucose levels were found very high at the beginning, and slightly (non-significantly) increased during the test. The increase of glucose level at the beginning of the test may be ascribed to an enhanced stress reaction of carp to reloading processes, when fish were kept in nets in a high density. Glucose level in unstressed carp reported in previous studies ranged within 2.8 - $5.6 \mathrm{mmol} \cdot \mathrm{l}^{-1}$ (Hertz et al. 1989), 2.0 - $5.0 \mathrm{mmol}^{-1} \mathrm{l}^{-1}$ (S vobodová et al. 1991) and $2.5-3.6 \mathrm{mmol} \cdot \mathrm{l}^{-1}$ (Bla s ko et al. 1992). Carp exposure to prolonged hypoxia, crowding stress and confinement in anglers' keepnets were reported to increase blood glucose levels from 5.0 to $10.0 \mathrm{mmol} \cdot \mathrm{l}^{-1}$ (van Raaij et al. 1996), from 4.7 to $6.9 \mathrm{mmol} \cdot \mathrm{l}^{-1}$ (Y in et al. 1995), and from $5.1 \mathrm{mmol} \cdot \mathrm{l}^{-1}$ (3.6 and $3.3 \mathrm{mmol} \cdot \mathrm{l}^{-1}$, respectively) to $8.0 \mathrm{mmol} \cdot \mathrm{l}^{-1}(7.3$ and $6.8 \mathrm{mmol} \cdot \mathrm{l}^{-1}$, respectively) in three experiments of Pottinger (1998).

The elevation of plasma lactate levels follows on respiratory activity under anaerobic conditions and reflects the imposition of severe exercise (Pottinger 1998). In our study, the highest level of plasma lactate $\left(9.17 \mathrm{mmol} \cdot \mathrm{l}^{-1}\right)$ was found at the beginning of the test, when the fish were stressed by hauling and exhausted by physical exercise in relatively hypoxic conditions. In Pottinger's study (1998), the confinement of fish in keepnets 
caused significant elevation of plasma lactate from 3.0 to $13.9 \mathrm{mmol} \cdot \mathrm{l}^{-1}$ and from 2.0 to 3.7 $\mathrm{mmol} \cdot \mathrm{l}^{-1}$. In our study, lactate levels decreased significantly $(p<0.05)$ to baseline levels $\left(2.89 \mathrm{mmol} \cdot \mathrm{l}^{-1}\right)$ during the transport, that indicates that the fish became calm after reloading procedure. The decrease of plasma lactate concentration during transportation also corresponds to the increase of water oxygen content in truck tanks.

At the end of the transport, a significant decrease in $\operatorname{ALT}(p<0.05), \operatorname{ALP}(p<0.01)$ and chloride $(p<0.05)$ levels, and a significant increase in ammonia $(p<0.01)$ concentration were found. Initial high ALT, ALP and chloride levels may be ascribed to the enhancement of fish basal metabolism during stressful reloading. Subsequent modulation of fish during transport leads to a decrease in their levels. Davis on et al. (1994) reported that hypoxic conditions caused an increase in chloride levels in fish. That corresponds to the results of our study, in which the highest chloride concentration was found in fish during hauling procedure, when the lowest water oxygen content was measured. During the transport, the oxygen content increased rapidly and chloride levels dropped significantly.

During exhaustive exercise (attack of prey, escape from predators, locomotion and migration processed, starvation), an increase of active energy demand occurs in fish (Smutná et al. 2002). Direct deamination of important tissue energy sources, i.e. amino acids, especially glutamate and aspartate (liver, muscle), histidine (kidney, muscle), serine (kidney) and glutamine (liver, kidney, muscle), leads to energy production (catabolism of glutamine and amino acids provides ATP molecules), and simultaneously to an increase of the ammonia level in fish (Smutná et al. 2002; Philip and Rajasree 1996). Production of an active actine-myosine complex, necessary for muscle contraction, leads to the splitting of ATP to ADP and $\mathrm{P}_{\mathrm{i}}$. Deamination of the AMP molecule, produced from the ADP molecule, leads to the production of IMP and ammonia. It means that in fish, burst exercise (i.e. high muscle activity) results in the production of ammonia. When the detoxification capabilities of the fish are exceeded, ammonia cumulates in the fish organism and acts as a toxicant (S mutná et al. 2002). In our study, the increase of ammonia level was caused by the enhancement of basic energy demand of fish transported (the increase of deamination processes in tissues), and by higher muscle activities of fish in space-quartered transport tanks.

Changes in haematological profile of peripheral blood have often been used as an indicator of stress exposure, though haematological indices results reported are found equivocal. Serious changes in haemogram are found in fish exposed to acute or chronic stress (Svobodová et al. 1994). As far as haematological indices of our study are concerned, twelve-hour transportation caused a significant increase in MCV level $(p<0.01)$, metamyelocytes $(p<0.05)$ and band neutrophils $(p<0.01)$.

In the blood of stressed fish, an increase in RBC, haemoglobin concentration and haematocrit level are observed (Doubek et al. 2003). Haemoglobin and haematocrit are often elevated during stress situations to increase oxygen carrying capacity and oxygen supply to the major organs in response to higher metabolic demands (Ruane et al. 1999). In our study, the highest RBC value was found in fish blood samples withdrawn during the transfer from storage ponds to transport tanks in Hluboká, when stress-induced RBC release from spleen to blood circulation was reported. RBC values then slightly decreased. Hb level was not affected, haematocrit and MCV values increased significantly.

Ruane et al. (2001) tested the effect of three-hour net confinement on common carp and found no specific changes in haemoglobin content. Haematocrit values decreased nonsignificantly after $0.5 \mathrm{~h}$ and $1.0 \mathrm{~h}$ confinement. During the recovery, the haematocrit levels increased and became comparable to control levels. The lowest haematocrit values of carp tested in our study were found during reloading fish into transport tanks. Haematocrit values increased significantly during the transportation. 
Ruane et al. (2002) exposed common carp to high stocking densities of 56.8 and $113.6 \mathrm{~kg} \cdot \mathrm{m}^{-3}$ for a period of 87 hours without finding any significant high-density effect on fish haematocrit and haemoglobin values. No changes in haematocrit values were also recorded in the Atlantic cod transport experiment by Staurnes et al. (1994).

Physiological responses of matrinxa juveniles (Brycon cephalus) juveniles were determined after the procedures of capturing, loading and $4 \mathrm{~h}$ transport at different densities (Urbinati et al. 2004). Haematocrit increased after loading, maintaining levels slightly high until the end of the experiment. No differences were verified in RBC number. Ac ere te et al. (2004) found an increase in haematocrit values and RBC after acute handling stress.

Results of white blood line observation showed a significant increase in counts of metamyelocytes $(p<0.05)$ and band neutrophils $(p<0.01)$, as well as a slight increase in leukocytes and myelocytes, and monocytes count reduction (both non-significant).

An important secondary effect of stress reported in fish (as a consequence of stress-related release of catecholamines) is immunosuppression (lymphocytopenia) and neutrophilia (Wiik et al. 1989; Svoboda 2001; Engelsma et al. 2003). Transport- and handlingstress leads to the elevation of plasma cortisol that is reported to have a direct cytolytic effect on lymphocytes (Wiik et al. 1989). These findings are in agreement with the data published by Wendelaar (1997), who reported that stress caused a rapid increase in neutrophils and a reduction of lymphocytes in peripheral blood. Reduction in lymphocyte count in stressed fish may partly be due to the extravasation of the cells and their penetration to the epithelium of gills, skin or intestine.

In our experiment, long-distance transport in high density tanks led to a slight increase of leukocyte count in the fish tested. The stress was also expressed in the increase in neutrophil granulocytes, mainly of juvenile forms (metamyelocytes and band neutrophils). Ortuno et al. (2001) reported that intense short-term crowding stress caused leukocytes release from head-kidney and their cumulation in blood circulation. Pulsford et al. (1994) detected an increased number of leukocytes, particularly phagocytes and damaged cells, in peripheral blood of stressed dab, Limanda limanda, along with a decrease in lymphocyte, thrombocyte and erythrocyte counts. In Espelid et al. (1996) study, after cortisol administration, a marked increase in the relative number of thrombocytes was reported, whereas granulocyte, monocyte and lymphocyte counts remained still relatively constant in Atlantic salmon.

In conclusion, pre-transport manipulation procedures were found to be very stressinducing and transport itself was relatively considerate for common carp. Although carp may quickly adapt to ambient environment, disturbances should be kept to a minimum to ensure optimal transport conditions, and subsequently high quality standards of fish products.

\section{Stresové zatížení kapra obecného (Cyprinus carpio L.) při dlouhodobém transportu}

U tř́letého kapra obecného byla sledována odpověd', tj. změny vybraných biochemických a hematologických parametrů, na stresové zatížení při dlouhodobém transportu ve speciálních transportních tancích. Dvanáctihodinový transport vedl k signifikantnímu zvýšení koncentrace amoniaku $(p<0.01)$, hodnoty MCV $(p<0.01)$, počtu metamyelocytů $(p<0.05)$ a neutrofilů - tyček $(p<0.01)$ a k signifikantnímu poklesu koncentrace $\mathrm{Cl}^{-}$ $(p<0.05)$ a laktátu $(p<0.05)$ a katalytické koncentrace $\operatorname{ALT}(p<0.05)$ a $\operatorname{ALP}(p<0.01)$. Katalytická koncentrace LDH $(p<0.01)$, AST $(p<0.05)$ a CK $(p<0.01)$ a hodnota PCV $(p<0.05)$ byly transportem statisticky významně ovlivněny, avšak nebyla prokázána časová závislost na době transportu. Hladiny kortisolu, glukosy a celkových proteinů $\mathrm{v}$ biochemickém profilu a hodnoty $\mathrm{Hb}, \mathrm{MCH}, \mathrm{MCHC}$ a počet erytrocytů, leukocytů a leukogram (vyjma metamyelocytů a neutrofilů - tyček) v hematologickém profilu ryb nebyly 
transportem signifikantně ovlivněny. Manipulační procesy spojené s nakládkou ryb byly pro testované ryby stresujícím faktorem, vlastní transport byl relativně šetrný.

\section{Acknowledgements}

This research was supported by the Ministry of Education, Youth and Sports of the Czech Republic (MSM project No. 6215712402).

\section{References}

ACERETE L, BALASCH JC, ESPINOSA E, JOSA A, TORT L 2004: Physiological responses in Eurasian perch (Perca fluviatilis, L.) subjected to stress by transport and handling. Aquaculture 237: 167-178

BARTON BA, PETER RE, PAULENCU CR 1980: Plasma cortisol levels of fingerling rainbow trout (Salmo gairdneri) at rest, and subjected to handling confinement, transport and stocking. Can J Fish Aquat Sci 37: 805-811

BLASKO J, FERNANDEZ J, GUTIERREZ J 1992: Variations in tissue reserves, plasma metabolites and pancreatic hormones during fasting in immature carp (Cyprinus carpio). Comp Biochem Physiol A 103: 357-363

DAVISON W, FRANKLIN CE, MC KENZIE JC 1994: Haematological changes in an Antarctic teleost, Trematomus bernacchii, following stress. Polar Biol 14: 463-466

DOUBEK J, BOUDA J, DOUBEK M, FÜRLL M, KNOTKOVÁ Z, PEJŘILOVÁ S, PRAVDA D, SCHEER P, SVOBODOVÁ Z, VODIČKA R 2003: Veterinární hematologie. Noviko Brno, 464 p. (in Czech).

ENGELSMA MY, HOUGEE S, NAP D, HOFENK M, ROMBOUT JH, VAN MUISWINKEL WB, LIDY VERBURG-VAN KEMENADE BM 2003: Multiple acute temperature stress affects leukocyte populations and antibody response in common carp, Cyprinus carpio L. Fish Shellfish Immun 15: 397-410

ERIKSON U, SIGHOLT T, SELAND A 1997: Handling stress and water quality during live transportation and slaughter of Atlantic salmon (Salmo salar). Aquaculture 149: 243-252

ESPELID S, L KKEN GB, STEIRO K, BØGWALD 1996: Effect of cortisol and stress on the immune system in Atlantic salmon ( Salmo salar L.). Fish Shellfish Immun 6: 95-110

HERTZ Y, MADAR Z, HEPHER B, BERTLER A 1989: Glucose metabolism in the common carp (Cyprinus carpio L.): the effects of cobalt and chromium. Aquaculture 76: 255-267

IZQUIERDO-PULIDO ML, HATAE K, HAARD NF 1992: Nucleotide catabolism and changes in texture indices during ice storage of cultured sturgeon, Acipenser transmontanus. J Food Biochem 16: 173-192

MAZEAUD MM, MAZEAUD F, DONALDSON EM 1977: Primary and secondary effects of stress in fish: some new data with a general review. Amer Fish Soc 106: 201-212

NAKAYAMA T, TOYODA T, OOI A 1994: Physical property of carp muscle during rigor tension generation. Fisheries Sci 60: 717-721

ORTUNO J, ESTEBAN MA, MESEGUER J 2001: Effects of short-term crowding stress on the gilthead seabream (Sparus aurata L.) innate immune response. Fish Shellfish Immun 11: 187-197

PHILIP GH, RAJASREE BH 1996: Action of cypermethrin on tissue transamination during nitrogen metabolism in Cyprinus carpio. Ecotox Environ Safe 34:174-179

POTTINGER TG 1998: Changes in blood cortisol, glucose and lactate in carp retained in anglers' keepnets. J Fish Biol 53: 728-742

PULSFORD AL, LEMAIRE-GONY S, TOMLINSON M, COLLINGWOOD N, GLYNN PJ 1994: Effects of acute stress on the immune system of the dab, Limanda limanda. Comp Biochem Physiol C 109: 129-139

ROBERTS RJ, SHEPHERD CJ 1997: Handbook of Trout and Salmon Disease. $3^{\text {rd }}$ Edition. Blackwell Science Ltd., Oxford, $179 \mathrm{p}$.

ROBERTSON L, THOMAS P, ARNOLD CR 1987: Plasma cortisol and secondary stress response of cultured red drum (Sciaenops ocellatus) to several transportation procedures. Aquaculture 68 : 115-130

RUANE MN, CARBALLO EC, KOMEN J 2002: Increased stocking density influences the acute physiological stress response of common carp Cyprinus carpio (L.). Aquac Res 33: 777-784

RUANE NM, HUISMAN EA, KOMEN J 2001: Plasma cortisol and metabolite level profiles in two isogenic strains of common carp during confinement. J Fish Biol 59: 1-12

RUANE NM, WENDELAAR BONGA SE, BALM PHM 1999: Differences between rainbow trout and brown trout in the regulation of the pituitary-interrenal axis and physiological performance during confinement. Gen Comp Endoc 115: 210-219

SCHRECK CB, SOLAZZI MF, JOHNSON SL, NICKELSON TE 1989: Transportation stress affects performance of coho salmon, Oncorhynchus kisutch. Aquaculture 82: 15-20

SMUTNÁ M, VORLOVÁ L, SVOBODOVÁ Z 2002: Pathobiochemistry of ammonia in the internal environment of fish (Review). Acta Vet Brno 71: 169-181

STAVE JW, ROBERTSON BS 1985: Hydrocortisone suppresses the chemiluminescent response of striped bass phagocytes. Dev Comp Immunol 9: 77-84

SVOBODA M 2001: Stress in fish - a review. Bull RIFCH Vodňany 37: 169-191 (in Czech) 
SVOBODOVÁ Z, KALÁB B, DUŠEK L, VYKUSOVÁ B, KOLÁŘOVÁ J, JANOUŠKOVÁ D 1999. The effect of handling and transport on the concentration of glucose and cortisol in blood plasma of common carp. Acta Vet Brno 68: 265-274

SVOBODOVÁ Z, MÁCHOVÁ J, VESELÝ V, MODRÁ H, SVOBODA M 2003: Veterinary toxicology. Laboratories. Part I. UVPS Brno, 179 p. (in Czech).

SVOBODOVÁ Z, PRAVDA D, PALÁČKOVÁ J 1991: Unified methods of haematological examination of fish. Methods No. 20. Research Institute of Fish Culture and Hydrobiology, Vodňany, 31 p.

SVOBODOVÁ Z, VYKUSOVÁ B, MÁCHOVÁ J 1994: The effect of pollutants on selected haematological and biochemical parameters in fish. In: MÜLLER R, LLOYD R (Eds.): Sublethal and chronic effects of pollutants on freshwater fish. FAO - Fishing News Books, Cambridge, pp. 39-52.

URBINATI EC, DE ABREU JS, DA SILVA CAMARGO AC, PARRA MAL 2004: Loading and transport stress of juvenile matrinxa (Brycon cephalus, Characidae) at various densities. Aquaculture 229: 389-400

VAN RAAIJ MTM, VAN DEN THILLARTM GEEJ, VIANEN GJ, PIT DSS, BALM PHM, STEFFENS AB 1996: Substrate mobilization and hormone changes in rainbow trout (Oncorhynchus mykiss, L.) and common carp (Cyprinus carpio, L.) during deep hypoxia and subsequent recovery. J Comp Physiol B 166: 443-452

WEIREICH CR, TOMASSO JR 1991: Confinement- and transport- induced stress on red drum juveniles: effect of salinity. Prog Fish Cult 53: 146-149

WENDELAAR SE 1997: The stress response in fish. Physiol Rev 77: 591-625

WIIK E, ANDERSEN K, UGLENES I, EGIDIUS E 1989: Cortisol-induced increase in susceptibility of Atlantic salmon, Salmo salar, to Vibrio salmonicida, together with the effects on the blood cell paterns. Aquaculture 83: 201-215

YIN Z, LAM TJ, SIN YM 1995: The effect of crowding stress on the non-specific immune response in fancy carp (Cyprinus carpio L.). Fish Shellfish Immun 5: 519-528 